\title{
Quantitative Analysis of Carbon in Carbon Steel Using SEM/EDS Followed by Error Correction Approach
}

\author{
Longjiang Zou ${ }^{1}$ and Quan Zhou ${ }^{2}$ \\ 1.2. Center of Material Characterization and Analysis, School of Materials Science and Engineering, \\ Dalian University of Technology, Dalian, China 116023
}

Carbon containing in carbon steel is one of important elements on material property and performance. Practically, the carbon concentration in steel is determined by chemical analysis such as Carbon-Sulfur analyzer in which considerable amount of powdery sample is required. When non-destructive analysis and spatial resolution on micro or sub-micro level are desired, an alternative analytical method becomes a critical solution.

Carbon analysis on carbon steel determined by SEM/EDS has been one of attractive topics on quantitative analysis of low-Z elements $(Z<11)(1)$. Due to variety of factors involving in the carbon $X-$ ray counts detected and further data analysis, quantitative analysis for carbon in steel by EDS has not became a reliable method in industrial application. This study focuses on carbon measurement from carbon steel by SEM/EDS using commercial software, followed by applying error correction based on the regression between measured value and certified value of 5 carbon steel standards with known carbon concentration.

An FE-SEM/EDS system (Zeiss Supra 55/Oxford INCA with SDD detector) was employed in this study. Total of 6 certified carbon steel standards was used with composition as shown on Fig. 1. EDS system was calibrated with $1.27 \% \mathrm{C}$ standard, then EDS analysis for carbon was conducted on the rest 5 standards, with 3 point-analysis on each standard. The carbon measurement data is shown on the left side of Fig. 2. A linear correlation $\left(\mathrm{R}^{2}=0.9999\right)$ was obtained by plotting the average value of carbon measured from each standard against the certified value of carbon on the standards as shown on the right side of Fig. 2. The regression formula was used for correction of measured carbon concentration to minimize the error from EDS measurement system. An error of $0.2 \% \mathrm{C}$ was observed on regression plot when certified carbon value reduced to zero. This is a systematic error of the EDS system. The slope of regression is 0.9738 , which is very close to 1.0000 , indicating that the measured data would be very close to the true value in the sample tested when systematic error is removed from the measured data.

Next, two steel samples, one high carbon and one low carbon steel, with known carbon concentration were analyzed under the same analytical condition. Test result shown on Fig. 3 indicated that similar level of error $(0.18 \% \mathrm{C}$ and $0.2 \% \mathrm{C})$ was present on the test data from the samples analyzed. The error was reduced to $0.01 \% \mathrm{C}$ after test data was corrected by regression formula as shown on Fig. 3 . This test result was acceptable from industrial perspective.

Several factors could have significant impact on the accuracy of carbon measurement such as the carbon buildup from e-beam contamination (2), the interference peaks from transition elements and heavy elements, and the peak shift etc. $(1,3)$. By using thermal FE emitters and SDD detector (shorter test time), quant optimization, limited type of sample to carbon steel exclusively and performing regression test prior to the analysis on unknown samples, the impact of these factors could be controlled and data generated could be with reasonable confidence. 


\section{References}

[1] V.D.Scott and G. Love, Journal of Analytical Atomic Spectrometry 14, (1998) 367-376

[2] D. Lau, A.E. Hughes, T.H. Muster, etc. Microsc. Microanal. 16, (2010) 13-20

[3] P. McSwiggen, N. Mori, T. Ohta, and C. Nielsen, Microsc. Microanal. 18 (2012) 1042-1043

Figure 1.

\begin{tabular}{|c|c|c|c|c|c|c|c|c|c|c|c|c|c|c|}
\hline $\begin{array}{c}\text { Standard } \\
\#\end{array}$ & $\mathrm{C}$ & $\mathrm{Si}$ & $\mathrm{Mn}$ & $\mathrm{P}$ & $\mathrm{S}$ & $\mathrm{Cr}$ & $\mathrm{Ni}$ & $\mathrm{Mo}$ & $\mathrm{Ti}$ & $\mathrm{V}$ & $\mathrm{Cu}$ & $\mathrm{W}$ & $\mathrm{Al}$ & $\mathrm{Fe}$ \\
\hline 1 & 0.06 & 0.03 & 0.06 & ---- & 0.03 & 0.49 & 0.03 & 0.3 & 0.01 & 0.24 & 0.28 & 0.38 & 0.07 & 98.02 \\
\hline 2 & 0.19 & 0.13 & 0.23 & 0.05 & 0.04 & 0.38 & 0.29 & 0.4 & 0.19 & 0.29 & 0.33 & 0.46 & 0.11 & 96.91 \\
\hline 3 & 0.37 & 0.19 & 1.02 & 0.02 & ---- & 0.22 & 0.08 & 0.23 & 0.05 & 0.17 & 0.23 & 0.09 & 0.18 & 97.15 \\
\hline 4 & 0.69 & 0.28 & 0.71 & 0.03 & 0.01 & 0.28 & 0.51 & 0.16 & 0.13 & 0.11 & 0.16 & 0.16 & 0.02 & 96.75 \\
\hline 5 & 0.98 & 0.37 & 0.34 & 0.01 & 0.03 & 0.16 & 0.39 & 0.08 & 0.15 & 0.06 & 0.09 & 0.25 & 0.02 & 97.07 \\
\hline 6 & 1.27 & 0.52 & 1.27 & 0.04 & 0.03 & 0.09 & 0.22 & 0.01 & 0.17 & 0.05 & 0.06 & 0.03 & 0.13 & 96.11 \\
\hline
\end{tabular}

Figure 2.

\begin{tabular}{|c|c|c|c|c|}
\hline $\begin{array}{c}\text { C \% in } \\
\text { standard }\end{array}$ & $\begin{array}{c}\text { Test 1 } \\
\%\end{array}$ & $\begin{array}{c}\text { Test 2 } \\
\%\end{array}$ & $\begin{array}{c}\text { Test 3 } \\
\%\end{array}$ & $\begin{array}{c}\text { Test } \\
\text { average } \\
\%\end{array}$ \\
\hline 0.06 & 0.26 & 0.25 & 0.26 & 0.257 \\
\hline 0.19 & 0.38 & 0.39 & 0.39 & 0.387 \\
\hline 0.37 & 0.58 & 0.55 & 0.56 & 0.563 \\
\hline 0.69 & 0.85 & 0.88 & 0.87 & 0.867 \\
\hline 0.98 & 1.15 & 1.15 & 1.17 & 1.157 \\
\hline
\end{tabular}

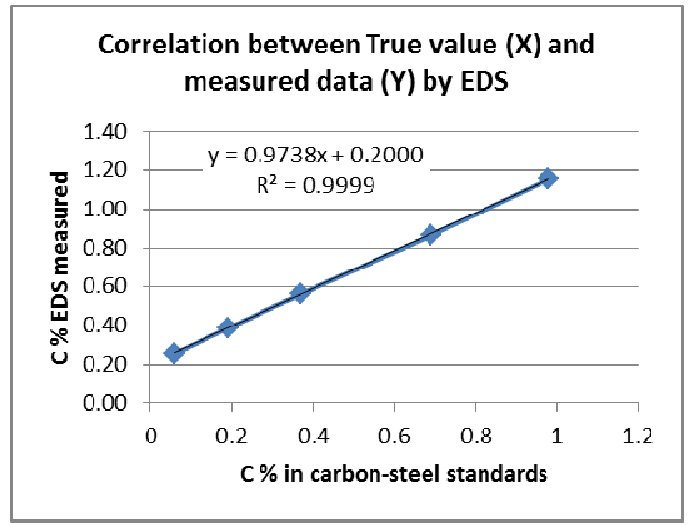

Figure 3.

\begin{tabular}{|l|c|c|c|c|c|c|}
\hline Sample & $\begin{array}{c}\text { Test 1 } \\
\%\end{array}$ & $\begin{array}{c}\text { Test 2 } \\
\%\end{array}$ & $\begin{array}{c}\text { Test 3 } \\
\%\end{array}$ & $\begin{array}{c}\text { Average } \\
\%\end{array}$ & $\begin{array}{c}\text { After correction } \\
\text { C \% }\end{array}$ & $\begin{array}{c}\text { Known } \\
\text { C \% }\end{array}$ \\
\hline $\begin{array}{l}\text { 100CrMn6 carbon steel } \\
\text { (high carbon steel) }\end{array}$ & 1.19 & 1.18 & 1.16 & 1.177 & 1.00 & 0.99 \\
\hline $\begin{array}{l}\text { 304 stainless steel } \\
\text { (low carbon steel, 18\% Cr) }\end{array}$ & 0.27 & 0.28 & 0.28 & 0.277 & 0.08 & 0.07 \\
\hline
\end{tabular}

Figure 1. Chemical composition of certified standards. Standard \# 6 was used for calibration of EDS system followed by EDS quant analysis on the rest of standards

Figure 2. Left: EDS quant analysis result from standards. Right: Linear correlation $\left(\mathrm{R}^{2}=0.9999\right)$ obtained between carbon concentration in standards and the EDS quant result. Notice that $0.2 \% \mathrm{C}$ systematic error was observed.

Figure 3. Test results from two steel samples with known $\mathrm{C} \%$ to validate the improvement on accuracy of carbon measurement. The error reduced to $0.01 \% \mathrm{C}$ level after corrected by regression. 